\title{
Books
}

\section{Recently Published Books}

Paul Bahn, Natalie Franklin, Matthias Strecker and Ekaterina Devlet, eds, Rock Art Studies: News of the World $V$

Published by: Archaeopress

Year of Publication: 2017, ISBN: 9781784913533

Hardback, viii+364 pages; highly illustrated throughout with 102 colour plates. $£ 19.00$

David A. Friedel, Arlen F. Chase, Anne S. Dowd and Jerry Murdock, Maya E Groups: Calendars, Astronomy, and Urbanism in the Early Lowlands

Published by: University Press of Florida

Year of Publication: 2017, ISBN: 9780813054353

Hardback, xxi+626 pages, b/w illustrations. $\$ 125.00$

Mark Hollabaugh, The Spirit and the Sky: Lakota Visions of the Cosmos

Published by: University of Nebraska Press

Year of Publication: 2017, ISBN: 9781496201454

Hardback, 264 pages, 10 photographs, 14 illustrations, 12 tables. $\$ 50.00$.

Frances Lynch and Peter Davey, eds., The Chambered Tombs of the Isle of Man: A Study by Audrey Henshall 1971-1978

Published by: Archaeopress

Year of Publication: 2017, ISBN: ISBN 9781784914684.

Hardback, iv+176 pages; illustrated throughout in colour and b/w (25 colour plates). $£ 30.00$

Rebecca O'Sullivan, Christina Marini and Julia Binnberg, eds, Archaeological Approaches to Breaking Boundaries: Interaction, Integration and Division: Proceedings of the Graduate Archaeology at Oxford Conferences 2015-2016

Published by: British Archaeological Reports

Year of Publication: 2017, ISBN: 9781407315133

Softback, 341 pages, Illustrated throughout in colour and b/w. Eight tables, 147 figures (48 in colour), 2 maps and 5 graphs. $£ 51.00$ 
Bryan E. Penprase, The Power of Stars

Published by: Springer

Year of Publication: 2017, ISBN: 9783319525976

Hardback, 350 pages, 43 b/w illustrations, 254 illustrations in colour. $£ 19.50$

Colin Renfrew, lain Morley and Michael Boyd, eds, Ritual, Play, and Belief in Evolution and Early Human Societies

Published by: Cambridge University Press

Year of Publication: 2017, ISBN: 9781107143562.

Hardback, 137 b/w illustrations, 1 table. $£ 90.00$

Apostolos Sarris, ed., Best Practices of Geolnformatic Technologies for the Mapping of Archaeolandscapes

Published by: Archaeopress

Year of Publication: 2017, ISBN: 9781784911621

Hardback iv +269 pages; illustrated throughout in colour and b/w. $£ 44.00$

Also available to download from Archaeopress Open Access.

Bettina Schulz Paulsson, Time and Stone: The Emergence and Development of Megaliths and Megalithic Societies in Europe

Published by: Archaeopress

Year of Publication: 2017, ISBN: 9781784916855

Hardback, xiv+376 pages; illustrated throughout in colour and b/w (71 plates in colour). $£ 45.00$

\section{Forthcoming Books}

Dragoş Gheorghiu, George Nash, Herman Bender and Emilia Pasztor, eds, Lands of the Shamans: Archaeology, Cosmology and Landscape

Published by: Oxbow Books, ISBN: 9781785709548

Paperback. Pre-order Special Price: $£ 28.50$

John Kelly and James A. Brown, Cahokia: City of the Cosmos

Published by: Oxbow Books, ISBN: 9781785708855

Paperback, 256p, H246 x W189 mm, b/w and colour illustrations. Pre-order Special Price $£ 28.50$

Fabio Silva, Towards Skyscape Archaeology

Published by: Oxbow Books. Series: Oxbow Insights in Archaeology, ISBN: 9781782979555

Paperback, 35 b/w illustrations. $£ 15.99$ 